\title{
BUFFALO COLOSTRUM: COMPOSITION AND IMMUNOGLOBULIN CONTENT IN RELATION TO IMMUNE STATUS OF NEWBORN CALVES
}

\author{
M.A.A. Abd El-Hady ${ }^{1}$, S.A. El-Ayouty ${ }^{2}$ and R.W. Raghib ${ }^{3}$ \\ 1- Animal Production Research Institute, Agriculture Research Center, Dokki, \\ Giza, Egypt, 2- Department of Animal Production, Faculty of Agriculture, \\ University of Mansoura, Egypt, 3- Animal Reproduction Research Institute, \\ Agriculture Research Center, El-Haram, Giza, Egypt.
}

\section{SUMMARY}

Colostrum samples from 98 buffalo cows in first to sixth lactation or more, as well as blood samples from 34 cows and their neonates were collected to investigate the influence of parity on: 1) Immunoglobulins (Ig) and chemical composition of colostrum and, 2) Passive immunity transfer to neonatal calves. Colostrum from the first 6 postpartum milkings was collected from each cow during two years (2004/2005) and a representative samples were used for analysis. Chemical composition (fat, protein, lactose, solid not fat and total solids) was performed on all the samples using Milko Scan, whereas immunoglobulin fractions (IgG, IgM and IgA) were determined during the first year (2004) using single radial immunodiffusion technique. Blood samples were obtained from 34 dams during the last month prepartum and from their offspring during the first month of life to evaluate the immunity transfer.

Weight of colostrum at first milking $(F M W)$ increased $(P<0.01)$ linearly with the advancement of lactation number. Mean of FMW in the first lactation cows was 1.45 $\mathrm{kg}$ compared with $4.70 \mathrm{~kg}$ of sixth lactation cows. The highest $(P<0.01) \mathrm{Ig}$ concentrations were observed in colostrum of first and second parities, whereas the lowest were in the sixth parity. Least squares means of Ig concentrations of the first 6 milkings for IgG were 6.31, 5.68, 5.03, 4.19, 3.67 and 3.99 $\mathrm{g} / \mathrm{dl}$; for IgM were 0.96, $0.89,0.82,0.69,0.69$ and 0.64 and for IgA were: $0.40,0.34,0.32,0.25,0.27$ and $0.24 \mathrm{~g} / \mathrm{dl}$. The chemical composition of colostrum differed significantly with lactation number. First lactation cows had higher $(P<0.01)$ colostral protein and consequently solid not fat (SNF) content compared to multiparous cows. However, colostral fat and lactose were lower $(P<0.01)$ in the first lactation cows compared to the older cows. The highest protein, total solids and SNF percent were in the first postpartum milking, and then the values decreased significantly with subsequent milkings. On the other hand, fat and lactose were the lowest in the first milking and increased $(P<0.01)$ gradually with milking intervals. Plasma IgG, IgM and IgA concentration increased in buffalo cows with the advancement of pregnancy to reach the highest levels at parturition. Similarly, plasma Ig of calves increased with the advancement of age from 7 to 28 days. However, plasma Ig concentration of dams and passive immunity transfer of calves were not affected significantly by lactation number of dams. The correlation coefficients among colostral Ig fractions and both protein and consequently SNF were highly significant. In general, parity and milking number are

Issued by The Egyptian Society of Animal Production 
major factors for alteration of immunity and chemical composition of buffalo colostrum.

Keywords: Colostrum, composition, immunoglobulin, passive immunity, buffalo

\section{INTRODUCTION}

Colostrum is the first postpartum mammary secretions containing extra amounts of immunoglobulins (Ig), proteins, vitamins and minerals in addition to hormones and related growth factors, which are vital to the neonatal calf (Campana and Baumrucker, 1995). Colostral intake supports the adaptation of calves to their new environment and establishes passive immunity (Stott and Fellah, 1983). In addition, colostrum supports development and function of gastrointestinal tract and influences metabolic and endocrine systems and neonatal nutritional status (Guilloteau et al. 1997; Hadorn et al., 1997; Buhler et al., 1998 and Hammon and Blum, 1999). Without colostrum consumption survival and health of the neonates are seriously influenced. Health problems including diarrhea and pneumonia are increased, thus growth rate and mortality rate are influenced (Nocek, et al., 1984 and Robison et al., 1988).

Passive immunity is provided when maternal colostrum containing large amount of $\mathrm{IgG}$ is fed to neonatal calves within the first few hours of birth (Quigley et al., 2001). Immunoglobulins are absorbed in the first period (perhaps 24- 36 hours) as intact molecules by apical tubular system of intestinal cells conferring immunity to the calf. The quantity of colostrum fed and its Ig content in addition to immediate intake plays crucial roles in the passive transfer of Ig to the calf (Quigley and Martin, 1994).

The classes of $\mathrm{Ig}$ includes $\operatorname{IgG}\left(\mathrm{IgG}_{1}\right.$ and $\left.\mathrm{IgG}_{2}\right)$ representing most of the Ig with the remainder as IgM and IgA. Butler (1994) reported that $\operatorname{IgG}_{1}$ comprises over $75 \%$ $(4.6 \mathrm{~g} / \mathrm{dl})$ of the $\operatorname{Ig}$ in colostral whey followed by $\operatorname{IgM}(0.68 \mathrm{~g} / \mathrm{dl}), \operatorname{IgA}(0.54 \mathrm{~g} / \mathrm{dl})$ and $\operatorname{IgG}_{2}(0.29 \mathrm{~g} / \mathrm{dl})$. Many researchers reported that $\operatorname{IgG}_{1}$ is transferred from the blood of the dam to the mammary gland during the last period of pregnancy, whereas $\operatorname{IgM}$ and IgA are synthesized in the mammary gland (Larsson et al., 1980 and Geene, 1984). The volume and concentration of Ig are influenced by lactation number and breed of cows (Klobasa et al., 1998). Colostral Ig was higher in primeparous buffalo cows compared to multiparous (Salama, et al., 1997). On the other hand, Mechor et al. (1992) noted that colostral Ig was not affected by parity. Murrah buffaloes had higher concentrations of protein and Ig than several crossbreeds of cows (Singh et al., 1993).

The Ig concentrations are related inversely to the volume of secreted colostrum (Pritchett et al., 1991). The first colostrum milked is the richest in its Ig content and the concentration decrease rapidly in the succeeding milkings (Stott et al., 1981 and Salama et al, 1997 and Kelly, 2003). The content of Ig was positively correlated with total solids (TS) and protein and negatively with fat (Mechor et al., 1992 and Salama et al., 1997). A few studies were conducted on colostral composition and immunity of buffaloes and their relations with parity. Therefore, this study was performed to evaluate the influence of parity on chemical composition and immunoglobulins of buffalo colostrum and passive immunity transfer to neonates. 


\section{MATERIAL AND METHODS}

The present study was conducted at Animal Production Research Station of Mahallet Mousa, Kafr El-Sheikh governorate belonging to APRI. Colostrum samples were collected as soon as possible after parturation from 98 buffalo cows in $1^{\text {st }}-6^{\text {th }}$ lactation or more during the years 2004 and 2005. Each cow was completely handmilked after induction of milk letdown with $10 \mathrm{IU}$ of oxytocin /cow spiecially with heifers (which was more difficult in milking). Colostrum was milked twice daily during the first 3 days postpartum. Colostrum weights were recorded for each milking and colostrum samples were taken in two clean vials and kept frozen until analysis. Cows were fed in the first year (2004) 3-5 kg kg concentrate, $4 \mathrm{~kg}$ berseem (Trifolium Alexanrenum) hay and $5 \mathrm{~kg}$ rice straw. In second year (2005), cows were fed the same rations as in 2004 plus $5-7 \mathrm{~kg}$ corn silage. Chemical composition of colostrum was determined using Milko Scan analyzer (Model 133 B, Denmark). The first day colostrum samples were diluted 1:1 with distelled water before releasing into Milko Scan. Immunoglobulins (Ig)G, $\operatorname{IgM}$ and $\operatorname{IgA}$ of colostrum were determined in colostral whey using single radial immunodifussion accoding to Fleenor and Stott (1981). Immunoglobulins were determined on only 44 cows in the $1^{\text {st }}$ year, whereas chemical composiotion of colostrum was determined in two years (2004 and 2005).

Blood samples of 34 cows and their calves were collected (in the $1^{\text {st }}$ year) from jugular vein into heparinized tubes three times during the last month of gestation for cows (at day 30, 15 and 0 of expected parturition date) and the first month of age for calves (day 7, 14 and 28 of age). Blood samples were centrifuged (at 3000 r.p.m for $15 \mathrm{~min}$.) to separate plasma and frozen until immunoglobulins determination. The newborn calves were separated from their dams after birth and offered colostrum artificially by nipple and bottle as soon as possible after calving for 3 days. After that, they were housed in individual concrete pens bedded with rice straw. Each calf was fed $10 \%$ of birth weight of whole buffalo milk artificially by nipple and bucket two times daily until 4 weeks of age.

Data of chemical composition, immunoglobulin concentration and colostrum milking weight were analyzed using the general linear model (GLM) of SAS (1996). The statistical model of colostral chemical composition included the effect of parity, time of sampling, experimental year and their interactions. Data concerning colostral and blood immunoglobulins of dams and calves were analyzed using two way classification model that included parity, time of sampling and their interaction. As well as, milking weight model included the effect of parity and experimental year. The correlation coefficients among colostral compositions and immunoglobulins also were estimated. The overall means were compared using Duncan's multiple range test (Duncan, 1955).

\section{RESULTS AND DISCUSSION}

\section{1- Weight of colostrum yield}

Least squares means of the first milking weight (FMW) are shown in Table (1). Buffalo cows at first lactation produced the lowest FMW $(1.45 \pm 0.54 \mathrm{~kg})$ compared with older cows. The value of FMW increased linearly $(\mathrm{P}<0.01)$ with the advancement of lactation number until the highest value $(4.70 \pm 0.54 \mathrm{~kg})$ at sixth 
lactation or more. Mean of FMW was higher in first year (2004) but without significant differences. The FMW was correlated negatively with colostral IgG and $\operatorname{IgA}(r=-0.242$ and -0.121 , respectively). The results are in agreement with Pritchett et al. (1991) and Tomkins and Jaster (1991).

Table 1. Least squares means of weight of first milking (FMW) of buffaloes at different parities

\begin{tabular}{|c|c|c|c|c|c|c|c|c|}
\hline \multirow{2}{*}{ Items } & \multicolumn{6}{|c|}{ Parity } & \multirow{2}{*}{ - SEM } & \multirow{2}{*}{$\begin{array}{c}\text { Mean of } \\
\text { Year }\end{array}$} \\
\hline & 1 & 2 & 3 & 4 & 5 & $6+$ & & \\
\hline Year: 2004 & 1.50 & 2.50 & 4.25 & 3.80 & 6.00 & 4.70 & 0.83 & 3.80 \\
\hline 2005 & 1.39 & 3.12 & 2.25 & 4.25 & 3.81 & 4.70 & 0.65 & 3.25 \\
\hline Mean of Parity & $1.45^{\mathrm{C}}$ & $2.81^{\mathrm{B}}$ & $3.25^{\mathrm{AB}}$ & $4.03^{\mathrm{AB}}$ & $4.20^{\mathrm{AB}}$ & $4.70^{\mathrm{A}}$ & & \\
\hline
\end{tabular}

\section{2- Chemical composition of colostrum}

Least square means of colostral chemical composition are presented in Table (2). Fat percentage of colostrum increased significantly $(\mathrm{P}<0.01)$ with advanced lactation number of cows. The highest value of fat was in $5^{\text {th }}$ lactation. A similar trend was found with lactose. Fat and lactose elevated $(\mathrm{P}<0.01)$ significantly with milking intervals. Protein and consequently solids not fat $(\mathrm{SNF})$ decreased $(\mathrm{P}<0.01)$ as lactation number of cows increased. The highest values were in first lactation cows (10.09\% and $14.0 \%$ for protein and $\mathrm{SNF}$, respectively). They declined $(\mathrm{P}<0.01)$ linearly with milking intervals to amounts typical for mature milk after three days postpartum. Total solids (TS) did not differ significantly among lactations, however TS decreased $(\mathrm{P}<0.01)$ linearly with milking intervals. The components of colostrum (without fat) were significantly higher $(\mathrm{P}<0.01)$ in second year $(2005$ vs. 2004). This may be related to prepartum feeding as buffalo cows were fed additional $5-7 \mathrm{~kg}$ corn silage during the $2^{\text {nd }}$ year. It was found that protein and TS levels were higher $(\mathrm{P}<0.01$ and $\mathrm{P}<0.05)$ in first lactation during $2^{\text {nd }}$ year than those in $1^{\text {st }}$ year $($ Fig. 1 and 2). A similar trend was found in fat and lactose but the highest level of fat was in $2^{\text {nd }}$ lactation and lactose was in $2^{\text {nd }}, 3^{\text {rd }}$ and $4^{\text {th }}$ lactation (Fig. 3 and 4). The results are in agreement with Salama et al. (1997), who found that colostral protein and TS were higher in the first lactation buffaloes compared with multiparous cows, however fat $\%$ was lower in first lactation (5.6\%) and increased with increasing lactation number. Whereas, Kume and Tanabe $(1993)$ found the highest $(\mathrm{P}<0.05)$ colostral protein was in $3^{\text {rd }}$ and lowest was in $1^{\text {st }}$ lactation number but colostral TS did not differ among parities. Quigley and Martin (1994) mentioned that colostral protein and fat contents were lower in $2^{\text {nd }}$ lactation cows.

Likewise, the highest level of lactose was in $5^{\text {th }}$ and $6^{\text {th }}$ milking during $2^{\text {nd }}$ year (Fig. 5). On the other hand, the highest levels of protein and consequently SNF were in $1^{\text {st }}$ and $2^{\text {nd }}$ milking (Fig. 6). A similar trend was found in buffaloes by Ghionna et al. (1987); Maria et al. (1990) and Singh et al. (1993) who reported that colostral protein and TS decreased in buffaloes $(\mathrm{P}<0.05)$ at $4^{\text {th }}$ milking postpartum. Oyeniyi and Hunter (1978) and Kume and Tanabe (1993) found TS and protein in colostrum of Holestein cows decreased $(\mathrm{P}<0.01)$ linearly with milking intervals. Ronge and Blum (1988) and Grutter and Blum (1991) reported that colostral compound except 
for lactose are particularly abundant in the $1^{\text {st }}$ colostrum, but they rapidly decreased within approximately 8 days to amounts typical for normal milk.

Table 2. The main effects of parity of buffaloes, milking time and year on chemical composition of colostrum

\begin{tabular}{|c|c|c|c|c|c|}
\hline Main Effects & Fat & Protein & Lactose & T.S & SNF \\
\hline Parity: 1 & $5.65^{b}$ & $10.09^{\mathrm{a}}$ & $3.07^{b}$ & 19.66 & $14.0^{\mathrm{a}}$ \\
\hline 2 & $6.19^{\mathrm{a}}$ & $8.87^{\mathrm{b}}$ & $2.86^{\mathrm{b}}$ & 18.73 & $12.54^{\mathrm{b}}$ \\
\hline 3 & $6.81^{\mathrm{a}}$ & $8.19^{\mathrm{bc}}$ & $3.38^{\mathrm{a}}$ & 19.20 & $12.40^{\mathrm{bc}}$ \\
\hline 4 & $7.18^{\mathrm{a}}$ & $8.22^{\mathrm{bc}}$ & $3.18^{\mathrm{ab}}$ & 19.43 & $12.24^{\mathrm{bc}}$ \\
\hline 5 & $7.70^{\mathrm{a}}$ & $8.15^{\mathrm{bc}}$ & $3.16^{\mathrm{ab}}$ & 19.8 & $12.09^{\mathrm{bc}}$ \\
\hline $6+$ & $7.48^{\mathrm{a}}$ & $8.13^{c}$ & $3.09^{\mathrm{ab}}$ & 19.54 & $12.06^{\mathrm{c}}$ \\
\hline SEM & 0.31 & 0.33 & 0.07 & 0.44 & 0.34 \\
\hline Milking No.:1 & $5.38^{\mathrm{c}}$ & $11.79^{\mathrm{a}}$ & $2.85^{\mathrm{e}}$ & $21.01^{\mathrm{a}}$ & $15.63^{\mathrm{a}}$ \\
\hline 2 & $6.98^{\mathrm{b}}$ & $10.10^{\mathrm{b}}$ & $2.92^{\mathrm{de}}$ & $20.86^{\mathrm{a}}$ & $13.88^{b}$ \\
\hline 3 & $7.26^{\mathrm{b}}$ & $8.53^{c}$ & $3.05^{\mathrm{cd}}$ & $19.66^{\mathrm{b}}$ & $12.40^{\mathrm{c}}$ \\
\hline 4 & $7.89^{\mathrm{a}}$ & $7.56^{\mathrm{d}}$ & $3.20^{\mathrm{bc}}$ & $19.46^{\mathrm{b}}$ & $11.57^{\mathrm{d}}$ \\
\hline 5 & $6.62^{\mathrm{b}}$ & $7.05^{\mathrm{de}}$ & $3.32^{\mathrm{ab}}$ & $17.73^{\mathrm{c}}$ & $11.11^{\mathrm{d}}$ \\
\hline $6+$ & $6.89^{\mathrm{b}}$ & $6.60^{\mathrm{e}}$ & $3.41^{\mathrm{a}}$ & $17.63^{\mathrm{c}}$ & $10.74^{\mathrm{d}}$ \\
\hline SEM & 0.31 & 0.33 & 0.07 & 0.44 & 0.34 \\
\hline Year: 2004 & 6.65 & 8.16 & 3.00 & 18.6 & 11.95 \\
\hline 2005 & 7.02 & $9.06^{* *}$ & $3.24^{* *}$ & $20.18^{* *}$ & $13.16^{* *}$ \\
\hline SEM & 0.175 & 0.185 & 0.045 & 0.25 & 0.20 \\
\hline
\end{tabular}

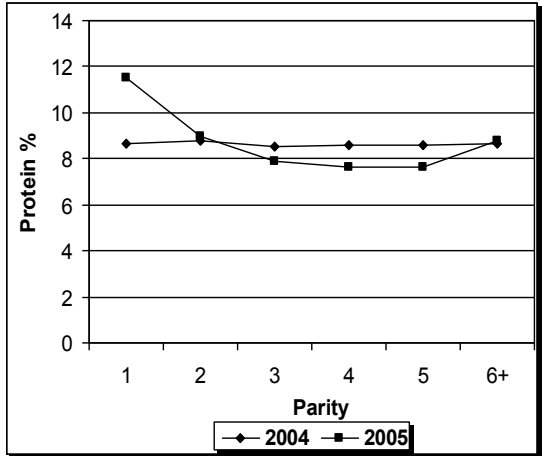

Fig. 1. Colostral protein $\%$ in different parities during two years

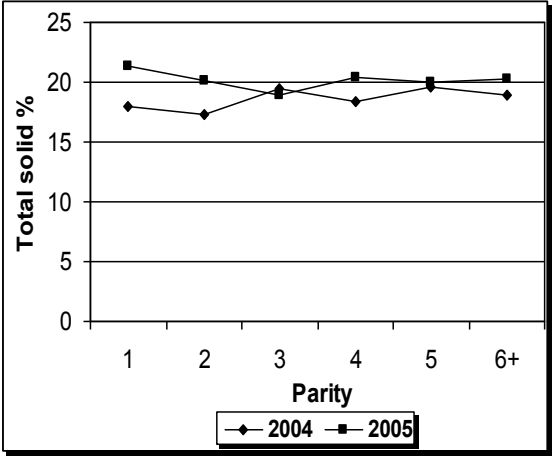

Fig. 2. Colostral total solid $\%$ in different parities during two years 


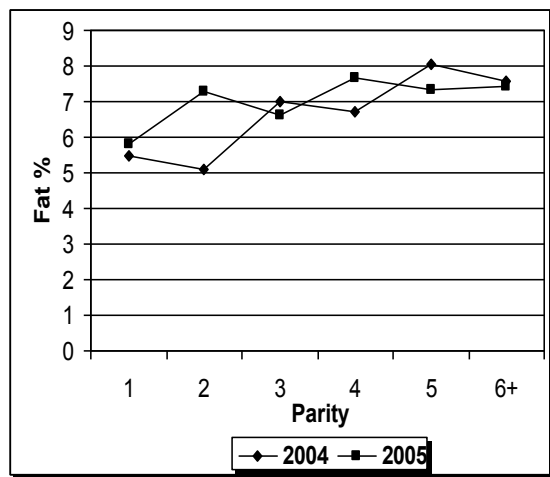

Fig. 3. Colostral fat $\%$ in different parities during two years

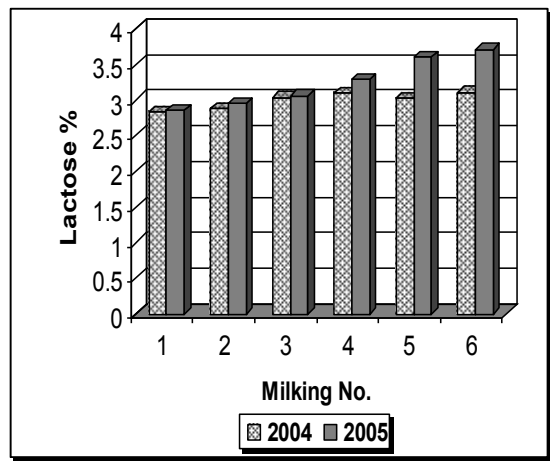

Fig. 5. Colostral lactose \% in milking intervals during two years

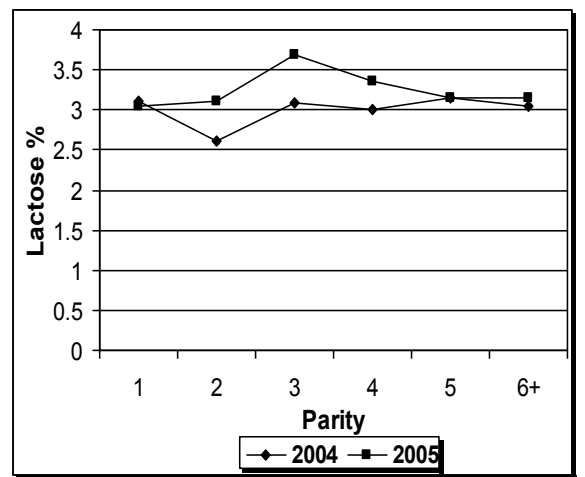

Fig. 4. Colostral lactose \% in different parities during two years

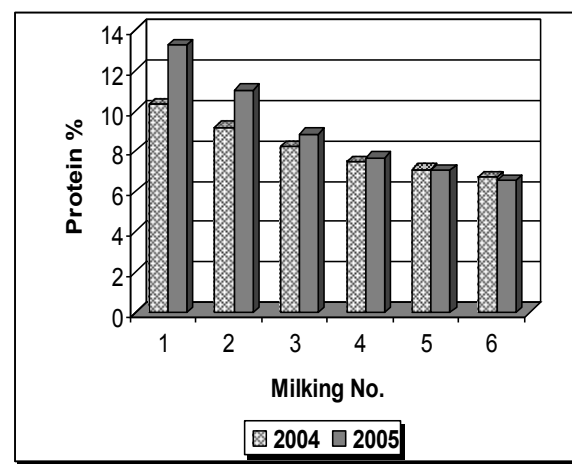

Fig. 6. Colostral protein \% in milking intervals during two years

\section{3- Colostral Immunoglobulins}

Colostral IgG concentrations of buffaloes decreased $(\mathrm{P}<0.01)$ significantly with the advancement of lactation number (Table 3). The highest level was in the first and second parities $(5.28$ and $5.44 \mathrm{~g} / \mathrm{dl})$ compared with the $5^{\text {th }}$ and $6^{\text {th }}$ lactational cows (4.51 and $3.99 \mathrm{~g} / \mathrm{dl})$. Also, the highest value of $\mathrm{IgG}$ was in the first milking (6.31 $\mathrm{g} / \mathrm{dl})$ and declined $(\mathrm{P}<0.01)$ gradually with time intervals. There were no significant effect of the interaction between parity and milking number. Similarly, colostral IgM and IgA concentrations (Tables 4 and 5) were the highest in the primiparous cows ( 0.88 and $0.33 \mathrm{~g} / \mathrm{dl}$, respectively) and declined significantly in the multiparous cows $(0.72$ and $0.28 \mathrm{~g} / \mathrm{dl}$, respectively). Furthermore, IgM and IgA were decreased $(\mathrm{P}<0.01)$ with milking number. These results agree with several studies. Mach and Pahud (1971) reported that the range of Ig of bovine mammary secretions was 5.2$8.7 \mathrm{~g} / \mathrm{dl}$ of IgG; $0.37-0.61 \mathrm{~g} / \mathrm{dl}$ of IgM and $0.32-0.62 \mathrm{~g} / \mathrm{dl}$ of IgA. As well as, Quigley and Martin (1994) found that mean concentration of colostral IgG, IgM and IgA of Jersey cows were 6.6; 0.24 and $0.17 \mathrm{~g} / \mathrm{dl}$, respectively. Klobasa et al. (1998) 
obtained similar range on Holstein cows. Salama et al. (1997) found that colostral Ig concentration was higher in the first lactation buffaloes compared with multiparous. On the other hand, previous studies conducted on other species referred to colostral $\mathrm{IgG}_{1}$ concentration was greater in multiparous cows (Devery-Pocius and Larson, 1983; Pritchett et al., 1991 and Levieux and Ollier, 1999). Also, Quigley and Martin (1994) found that colostral IgM increased linearly as lactation number increased, however IgG and IgA were not affected significantly by lactation number of Jersey cows. Likewise, Mechor et al. (1992) found that lactation number had no significant effect on Ig content of colostrum. Oyeniyi and Hunter (1978), Kelly (2003) and Abd El-Hady et al. (2005) observed that colostral IgG concentration declined significantly $(\mathrm{P}<0.01)$ with milking number.

Table 3. Colostral IgG (g/dl) of buffalo cows as affected by parity and milking Number

\begin{tabular}{|c|c|c|c|c|c|c|c|c|}
\hline \multirow{2}{*}{ Items } & \multicolumn{6}{|c|}{ Milking No. } & \multirow{2}{*}{ SEM } & \multirow{2}{*}{$\begin{array}{c}\text { Mean of } \\
\text { parity }\end{array}$} \\
\hline & 1 & 2 & 3 & 4 & 5 & 6 & & \\
\hline Parity: 1 & 6.84 & 6.12 & 5.13 & 4.60 & 4.48 & 4.54 & 0.46 & $5.28^{\mathrm{AB}}$ \\
\hline 2 & 6.51 & 5.31 & 5.60 & 5.02 & 4.87 & 5.32 & 0.62 & $5.44^{\mathrm{A}}$ \\
\hline 3 & 6.54 & 6.63 & 5.05 & 4.11 & 3.28 & 3.51 & 0.40 & $4.85^{\mathrm{ABC}}$ \\
\hline 4 & 6.40 & 5.28 & 5.52 & 4.73 & 3.45 & 3.37 & 0.36 & $4.79^{\mathrm{BC}}$ \\
\hline 5 & 6.02 & 5.55 & 4.69 & 3.36 & 3.62 & 3.83 & 0.61 & $4.51^{\mathrm{C}}$ \\
\hline $6+$ & 5.54 & 5.17 & 4.18 & 3.33 & 2.33 & 3.43 & 0.49 & $3.99^{\mathrm{D}}$ \\
\hline Mean of milking & $6.31^{\mathrm{A}}$ & $5.68^{\mathrm{B}}$ & $5.03^{\mathrm{C}}$ & $4.19^{\mathrm{D}}$ & $3.67^{\mathrm{E}}$ & $3.99^{\mathrm{ED}}$ & 0.20 & \\
\hline
\end{tabular}

Table 4. Colostral IgM (g/dl) of buffalo cows as affected by parity and milking number

\begin{tabular}{cccccccccc}
\hline \multirow{2}{*}{ Items } & $\mathbf{1}$ & $\mathbf{2}$ & $\mathbf{3}$ & $\mathbf{4}$ & $\mathbf{5}$ & $\mathbf{6}$ & SEM & $\begin{array}{c}\text { Mean of } \\
\text { parity }\end{array}$ \\
\cline { 2 - 9 } & Parity: $\mathbf{1}$ & 0.98 & 0.98 & 1.00 & 0.62 & 0.83 & 0.88 & 0.11 & $0.88^{\mathrm{a}}$ \\
$\mathbf{2}$ & 0.95 & 0.79 & 0.90 & 0.77 & 0.87 & 0.93 & 0.14 & $0.87^{\mathrm{a}}$ \\
$\mathbf{3}$ & 0.99 & 0.98 & 0.73 & 0.64 & 0.61 & 0.50 & 0.09 & $0.74^{\mathrm{ab}}$ \\
$\mathbf{4}$ & 0.96 & 0.80 & 0.87 & 0.72 & 0.57 & 0.58 & 0.08 & $0.75^{\mathrm{ab}}$ \\
$\mathbf{5}$ & 1.12 & 0.89 & 0.69 & 0.68 & 0.67 & 0.40 & 0.14 & $0.74^{\mathrm{b}}$ \\
$\mathbf{6}+$ & 0.77 & 0.93 & 0.75 & 0.74 & 0.58 & 0.57 & 0.11 & $0.72^{\mathrm{b}}$ \\
Mean of milking & $0.96^{\mathrm{A}}$ & $0.89^{\mathrm{AB}}$ & $0.82^{\mathrm{B}}$ & $0.69^{\mathrm{C}}$ & $0.69^{\mathrm{C}}$ & $0.64^{\mathrm{C}}$ & 0.05 & \\
\hline a, b, c Means with differing superscripts within the same column of parity are significantly \\
different at (P<0.05) \\
A, B, C Means with differing superscripts within the same row of milking No. are significantly \\
different at $(\mathrm{P}<0.01)$
\end{tabular}


Table 5. Colostral IgA (g/dl) of buffalo cows as affected by parity and milking number

\begin{tabular}{|c|c|c|c|c|c|c|c|c|}
\hline \multirow{2}{*}{ Items } & \multicolumn{6}{|c|}{ Milking No. } & \multirow{2}{*}{ SEM } & \multirow{2}{*}{$\begin{array}{c}\text { Mean of } \\
\text { parity }\end{array}$} \\
\hline & 1 & 2 & 3 & 4 & 5 & 6 & & \\
\hline Parity: 1 & 0.44 & 0.36 & 0.34 & 0.30 & 0.30 & 0.27 & 0.03 & $0.33^{\mathrm{A}}$ \\
\hline 2 & 0.43 & 0.30 & 0.35 & 0.24 & 0.31 & 0.32 & 0.04 & $0.33^{\mathrm{A}}$ \\
\hline 3 & 0.39 & 0.36 & 0.31 & 0.27 & 0.25 & 0.20 & 0.02 & $0.30^{\mathrm{AB}}$ \\
\hline 4 & 0.41 & 0.33 & 0.35 & 0.30 & 0.25 & 0.25 & 0.02 & $0.32^{\mathrm{AB}}$ \\
\hline 5 & 0.41 & 0.33 & 0.28 & 0.19 & 0.25 & 0.21 & 0.04 & $0.28^{\mathrm{B}}$ \\
\hline $6+$ & 0.35 & 0.36 & 0.28 & 0.22 & 0.26 & 0.21 & 0.03 & $0.28^{\mathrm{B}}$ \\
\hline Mean of milking & $0.40^{\mathrm{A}}$ & $0.34^{\mathrm{B}}$ & $0.32^{\mathrm{B}}$ & $0.25^{\mathrm{C}}$ & $0.27^{\mathrm{C}}$ & $0.24^{\mathrm{C}}$ & 0.01 & \\
\hline
\end{tabular}

different at $(\mathrm{P}<0.01)$.

\section{4- Plasma Immunoglobulins}

As shown in Table (6), a slight effect of parity on plasma IgG and IgA of cows but without significant differences. Plasma $\operatorname{IgG}$ and $\operatorname{IgA}$ tended to increase with the increasing of parity. The lowest value of IgM concentration was in $2^{\text {nd }}$ lactation cows and tended to increase $(\mathrm{P}<0.01)$ with the advancement of lactation number. Plasma IgG and $\operatorname{IgM}$ were elevated linearly $(\mathrm{P}<0.01)$ with time intervals until calving, however plasma IgA tended to increase with time but without significant differences.

Passive immunity transfer to neonatal buffalo calves as affected by parity of their dams also were studied (Table 7). It was found that the highest levels of plasma IgG $(\mathrm{P}<0.1)$ and $\operatorname{IgM}(\mathrm{P}=0.15)$ were in the neonates from the $3^{\text {rd }}$ and $4^{\text {th }}$ lactation dams. The lowest values were of $1^{\text {st }}$ and $2^{\text {nd }}$ lactations, although their colostrum had higher IgG and IgM concentrations. This may be explained by the lower colostral yield of these cows as compared with multiparous, so that the colostral intake by neonates was lower. A similar curve was observed with plasma IgA which had higher $(\mathrm{P}<0.05)$ level in calves from $5^{\text {th }}$ parity dams. Quigley et al. $(2001)$ reported that plasma $\mathrm{IgG}$ concentration in calves fed $\geq 122 \mathrm{~g}$ of $\mathrm{IgG}$ was $\geq 1.0 \mathrm{~g} / \mathrm{dl}$ indicating successful transfer of passive immunity. They also concluded the amount of IgG that fed to calves should not be less than $100 \mathrm{~g} /$ dose to transfer adequate amount of passive immunity. The present results indicated that mean of colostral IgG concentration in $1^{\text {st }}$ milking was $6.51 \mathrm{~g} / \mathrm{dl}$ and the mean of plasma IgG concentration of neonates was $2.08 \mathrm{~g} / \mathrm{dl}$ that indicating successful passive immunity transfer. Plasma IgG of calves was elevated to the maximum level at $14^{\text {th }}$ day of age and then tended $(\mathrm{P}<0.1)$ to decrease. Whereas, IgM and IgA were not affected by age of calf. Similar trend to the effect of age of calf was found by Rajala and Castren (1995). 
Table 6. Least squares means of plasma immunoglobulins (g/dl) of buffalo cows at prepartum period

\begin{tabular}{|c|c|c|c|}
\hline \multirow{2}{*}{ Items } & \multicolumn{3}{|c|}{ Plasma immunoglobulins of cows } \\
\hline & IgG & IgM & IgA \\
\hline Parity: 1 & 2.48 & $0.35^{\mathrm{ab}}$ & 0.086 \\
\hline 2 & 2.38 & $0.29^{\mathrm{b}}$ & 0.088 \\
\hline 3 & 2.59 & $0.39^{\mathrm{a}}$ & 0.106 \\
\hline 4 & 2.66 & $0.36^{\mathrm{ab}}$ & 0.098 \\
\hline 5 & 2.81 & $0.35^{\mathrm{ab}}$ & 0.095 \\
\hline $6+$ & 2.49 & $0.41^{\mathrm{a}}$ & 0.14 \\
\hline SEM & 0.18 & 0.025 & 0.02 \\
\hline \multicolumn{4}{|c|}{ Time Prepartum (day): } \\
\hline-30 & $2.03^{\mathrm{C}}$ & $0.29^{\mathrm{B}}$ & 0.095 \\
\hline-15 & $2.49^{\mathrm{B}}$ & $0.37^{\mathrm{A}}$ & 0.097 \\
\hline $\mathbf{0}$ & $3.18^{\mathrm{A}}$ & $0.42^{\mathrm{A}}$ & 0.114 \\
\hline SEM & 0.13 & 0.02 & 0.015 \\
\hline
\end{tabular}

Table 7. Least squares means of plasma immunoglobulins (g/dl) of newborn calves

\begin{tabular}{ccccc}
\hline \multirow{2}{*}{ Items } & \multicolumn{3}{c}{ Plasma immunoglobulins of calves } \\
\cline { 2 - 5 } Parity: $\mathbf{1}$ & IgG & IgM & IgA \\
\cline { 2 - 4 } & $\mathbf{2}$ & 1.79 & 0.27 & $0.064^{\mathrm{b}}$ \\
$\mathbf{3}$ & 1.94 & 0.26 & $0.058^{\mathrm{b}}$ \\
$\mathbf{4}$ & 2.29 & 0.29 & $0.129^{\mathrm{ab}}$ \\
& $\mathbf{5}$ & 2.32 & 0.27 & $0.088^{\mathrm{b}}$ \\
& $\mathbf{6}+$ & 2.11 & 0.31 & $0.195^{\mathrm{a}}$ \\
SEM & & 2.04 & 0.23 & $0.075^{\mathrm{b}}$ \\
Age of calf (day): & 0.16 & 0.021 & 0.025 \\
& $\mathbf{7}$ & & & \\
& $\mathbf{1 4}$ & 1.94 & 0.29 & 0.127 \\
& $\mathbf{2 8}$ & 2.30 & 0.25 & 0.084 \\
SEM & 2.01 & 0.27 & 0.094 \\
\hline
\end{tabular}

${ }^{\mathrm{a}, \mathrm{b}}$ Means with differing superscripts within the same column of parity are significantly different at $(\mathrm{P}<0.05)$.

\section{5- Correlation coefficients}

Chemical composition of colostrum has been studied in association with colostral immunoglobulins through correlation coefficients (r). Concentration of IgG, IgM and IgA were highly correlated with protein and SNF \% (Table 8). However, Ig fractions were negatively correlated with lactose and fat $\%$. In addition, negative correlations were found between FMW and IgG or IgA. Highly significant correlations were noted among IgG, IgM and IgA. Colostral protein was negatively correlated $(\mathrm{P}<0.01)$ with both fat and lactose $(r=-0.25$ and -0.52 , respectively). 
These findings are in agreement with Ghionna et al. (1987); Mechor et al. (1992) and Salama et al. (1997) who reported that colostral Ig was highly positively correlated with protein and negatively with fat $(\mathrm{r}=-0.21)$. As well, Pritchett et al. (1991) , agreement with our results, noted a negative correlation $(\mathrm{r}=-0.29)$ between IgG and FMW. Mechor et al. (1992) and Quigley and Martin (1994) found similar trend where they reported significant correlation between $\operatorname{IgG}, \operatorname{IgM}$ and $\operatorname{IgA}$, also between IgG and both protein and TS.

Table 8. Correlation coefficients between colostral components of buffalo cows.

\begin{tabular}{lccllllll}
\hline Items & Fat & Protein & Lactose & TS & SNF & FMW & IgG & IgM \\
\hline Protein & $-0.250^{* *}$ & & & & & & & \\
Lactose & 0.071 & $-0.523^{* *}$ & & & & & & \\
T.S & $0.668^{* *}$ & $0.534^{* *}$ & $-0.194^{*}$ & & & & & \\
SNF & $-0.212^{*}$ & $0.974^{* *}$ & $-0.333^{* *}$ & $0.585^{* *}$ & & & & \\
IgG & $-0.219^{*}$ & $0.493^{* *}$ & $-0.335^{* *}$ & 0.168 & $0.459^{* *}$ & -0.242 & & \\
IgM & -0.169 & $0.319^{* *}$ & $-0.186^{*}$ & 0.097 & $0.311^{* *}$ & 0.089 & $0.637^{* *}$ & \\
IgA & $-0.282^{* *}$ & $0.464^{* *}$ & $-0.399^{* *}$ & 0.078 & $0.410^{* *}$ & -0.121 & $0.713^{* *}$ & $0.623^{* *}$ \\
\hline
\end{tabular}

FMW: weight of first milking

* $\mathrm{P}<0.05 ; * * \mathrm{P}<0.01$

\section{REFERENCES}

Abd El-Hady, M. A. A., R.W. Raghib and G. H. Metry, 2005. Influence of selenium and vitamin $\mathrm{E}$ administration of late pregnancy buffalo cows on maternal transfer of selenium and immunoglobulins to their calves. J. Agric. Sci. Mansoura Univ., 30(12): $7413-7424$.

Buhler, C., H. Hammon, G.L. Rossi, J.W. Blum, 1998. Small intestinal morphology in eight-day-old calves fed colostrum for different durations or only milk replacer and treated with long- $\mathrm{R}^{3}$-insulin-like growth factor I and growth hormone. J. Anim. Sci. 76: 758-765.

Bulter, JE. 1994. Passive immunity and immunoglobulin diversity. In Indogenous Antimicrobial Agents of Milk-recent Development. IDF Special Issue 9404 4: 1450 .

Campana, W.M. and C.R. Baumrucker, 1995. Hormones and growth factors in bovine milk. In: R.G. Jensen (Ed.) Handbook of Milk Composition. Pp 476-494. Academic Press, San Diego, CA.

Devery-Pocius, J.E. and B.L. Larson, 1983. Age and previous lactations as factors in the amount of bovine colostral immunoglobulins. J. Dairy Sci. 66: 221.

Duncan, D. B. (1955). Multiple range and multiple F-test. Biometrics, 11:1-42.

Fleenor, W.A. and G.H. Stott, 1981. Single radial immunodiffusion analysis for quantitation of colostral immunoglobulin concentration. J. Dairy Sci. 64: 740.

Geene, J.J. 1984. Colostrum and immunity-possible factors which may affect the state of immunity in young calves. Ph.D. Diss., Royal Univ. Utrecht, Neth.

Ghionna, C.M., M. Verna, G. Catillo and M. Angelucci, 1987. Chemical composition of water buffalo colostrum in six milkings after calving. Annali dell'Istituto Sperimentale per la Zootecnia. Italy. 20:59 (C.F. Salama et al., 1997). 
Grutter, R. and J.W. Blum, 1991. Insulin-like growth factor I in neonatal calves fed colostrum or whole milk and injected with growth hormone. J. Anim. Physiol. Anim. Nutr. 66: 231-239.

Guilloteau, P., I.Le. Hueron-Luron, J.A. Chayvialle, R. Toullec, R. Zabielski, and J.W. Blum, 1997. Gut regulatory peptides in young cattle and sheep. J. Vet. Med. A $44: 1-23$.

Hadorn, U., H. Hammon, R.M. Bruckmaier, and J.W. Blum, 1997. Delaying colostrum intake by one day has important effects on metabolic traits and on gastrointestinal and metabolic hormones in neonatal calves. J. Nutr. 127:20112023.

Hammon, H.M. and J.W. Blum, 1999. Plasma free amino acids in neonatal calves are influemced by feeding colostrum for different durations or by feeding only milk replacer. J. Anim. Physiol. Anim. Nutr. 82: 193-204.

Kelly, G.S. 2003. Bovine colostrums: A review of clinical uses. Alternative Medicine Review 8: 378-394.

Klobasa, F., M.C. Goel and E. Werhahn, 1998. Comparison of freezing and lyophilizing for preservation of colostrum as a source of immunoglobulins for calves. J. Anim. Sci. 76: 923-926.

Kume, S. and S. Tanabe, 1993. Effect of parity on colostral mineral concentrations of Holestein cows and value of colostrum as a mineral source for newborn calves. J. Dairy Sci. 76: 1654-1660.

Larsson, B.L., M.L. Leary and J.E. Devery, 1980. Immunoglobulin production and transport by mmary glands. J. Dairy Sci. 63: 665.

Levieux, D. and A. Ollier, 1999. Bovine immunoglobulin G, beta-lactoglobulin, alpha-lactoglobulin and serum albumin in early postpartum period. J. Dairy Res. 66:421-430.

Mach, J.P and J.J. Pahud, 1971. Secretory IgA, a major immunoglobulin in most bovine external secretions. J. Immunol 106: 552-563.

Maria, C.G., M. Verna, G. Catillo and C.G. De-Maria, 1990. Chemical composition of colostrum of water buffaloes in six post-partum milkings. Proceeding of the $2^{\text {nd }}$ Worled Buffalo Congress, India, 4: 231.

Mechor, G.D., Y.T. Grohn, L.R. McDowell and R.J. Van Saun, 1992. Specific gravity of bovine colostrum immunoglobulins as affected by temperature and colostrum components. J. Dairy Sci. 75: 3131.

Nocek, J.E., D.G. Braund and R.G. Warner, 1984. Influence of neonatal colostrum administration on immunoglobulin, and continued feeding of colostrum on calf gain, health and serum protein. J. Dairy Sci. 67: 319-323

Oyeniyi, O.O. and A.G. Hunter, 1978. Colosral constituents including immunoglobulins in the first three milkings postpartum. J. Dairy Sci. 61: 44.

Pritchett, L.C., C.C. Gay, T.E. Besser and D.D. Hancock, 1991. Management and production factors influencing immunoglobulin G1 concentration in colostrum from Holestien cows. J. Dairy Sci. 74: 2336-2341.

Quigley, J.D. and K.R. Martin, 1994. Immunoglobulin concentration, specific gravity and nitrogen fractions of colostrum from Jersey cattle. J. Dairy Sci. 77: 264-269.

Quigley, J.D., R.E. Strohbehn, C.J. Kost and M.M. O'Brien, 2001. Formulation of colostrum supplements, colostrum replacers and acquisition of passive immunity in neonatal calves. J. Dairy Sci. 84: 2059-2065. 
Rajala, P. and H. Castren, 1995. Serum immunoglobulin concentrations and helth of dairy calves in two management systems from birth to 12 weeks of age. J. Dairy Sci. 78: 2737-2744.

Robison, J.D., G.H. Stott and S.K. De Nise, 1988. Effects of passive immunity on growth and survival in the dairy heifer. J. Dairy Sci. 71:1283-1287

Ronge, H. and J.W. Blum, 1988. Somatomedin C and other hormones in dairy cows around parturition, in newborn calves and in milk. J. Anim. Physiol. Anim. Nutr. 60: 168-176.

Salama, M.A.M. M.M. Mohey El-Deen and Shafika R. Ishak 1997. Effect of parity on the chemical composition of water buffalo's colostrum. Egypt J. Appl. Sci. 12: 31-43.

SAS, 1996. SAS User's Guide, SAS (Statistical Analysis System) Institute, Cary, NC.

Singh, A., S.P. Ahuja and B. Singh, 1993. Individual variation in the composition of colostrum and absorption of colostral antibodies by the precolostral buffalo calf. J. Dairy Sci. 76: 1148.

Stott, G.H and A. Fellah, 1983. Colostral immunoglobulin absorption linearly related to concentration for calves. J. Dairy Sci. 66: 1319-1328.

Stott, GH., W.A. Fleenor, and W.C. Kleese, 1981. Colostral immunoglobulin in two fractions of first milking postpartum and five additional milkings. J. Dairy Sci. 64: 459-465.

Tomkins, T. and E.H. Jaster, 1991. Preruminant calf nutrition. Vet. Clin. North Am. Food Anim. Pract. 7: 557-576. 
السرسوب فـى الجـاموس: التركيب الكيمـاوى والمحتوى مـن الأجسام المناعيـة وعلاقتـهـ بالحالة المناعية فى العجول حديثة الولادة ماجد عبد لهادى عبد العزيز عبدالهادى'، السيد أحمد العيوطى"، رضا وهيب راغبّ

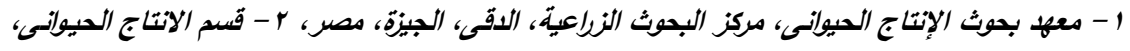

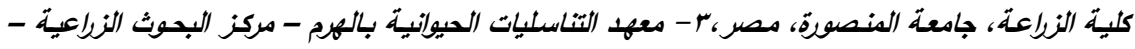

تم جمع عينات سرسوب من هـ جاموسة فى المواسم الانتاجية من الأول الى السادس فأكثر ، كذللك تم

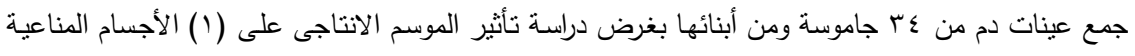

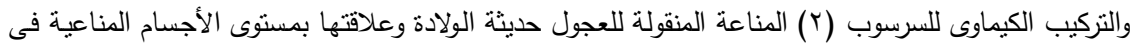

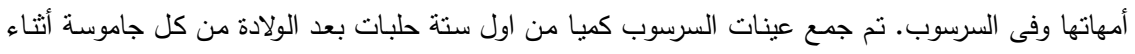

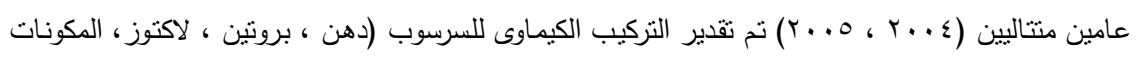

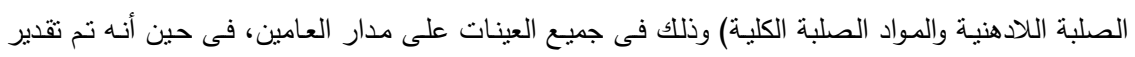

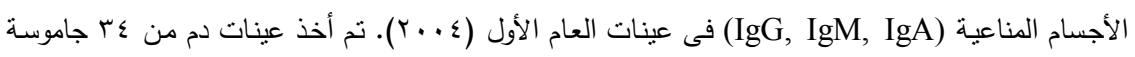

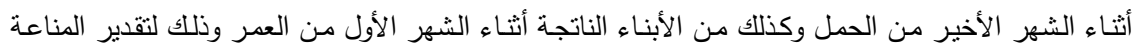

وقد نلخصت أهم النتائج فى الآتى: ازداد وزن أول حلبة من السرسوب زيادة طردية (P<0.01) مع النقدم

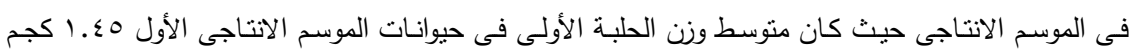

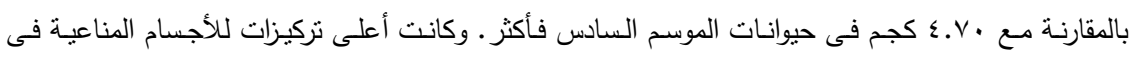

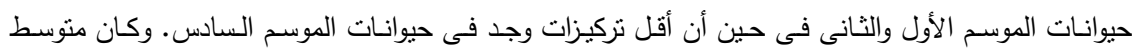

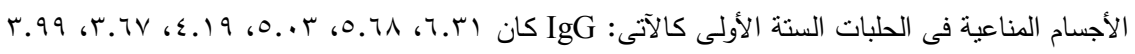

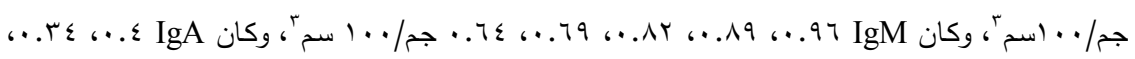

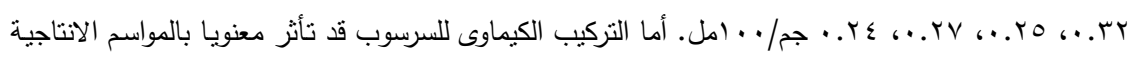

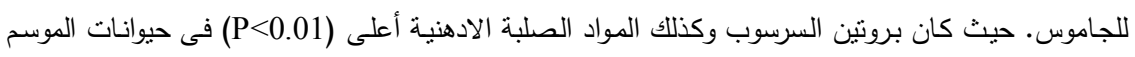

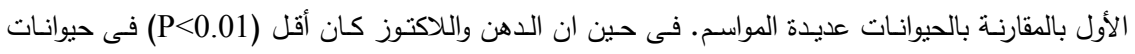

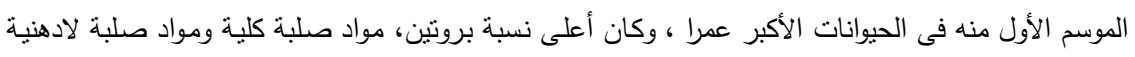

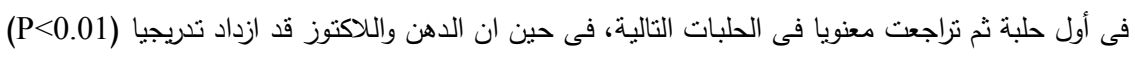

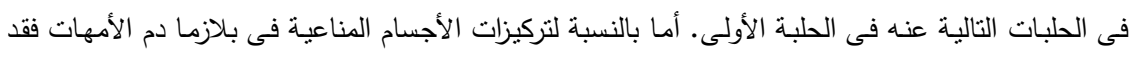

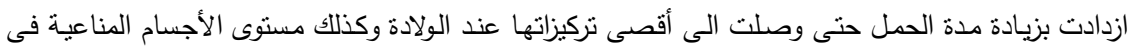

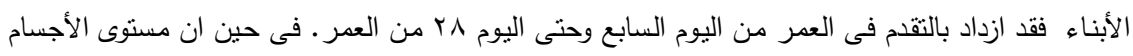

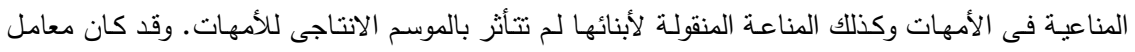


الارتباط بين الأجسام المناعية فى السرسوب وكلا من البروتين والمواد الصلبة اللادهنية مرتقع معنويا وكذلك بين الأجسام المناعية وبعضها. يستخلص من هذه الدراسـة أن كلا من الموسم الانتاجى للجاموس ورقم الحلبة (أو الوقت بعد الولادة) تعد العد

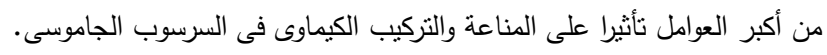

